\title{
Comparison of Superficial Surgical Site Infection in Simple Interrupted and Hybrid Mattress Suture after Posterior Approach for Spine Surgery
}

Ajid Risdianto, Rully Hanafi Dahlan, Achmad Adam, Firman Priguna, Muhammad Zafrullah Arifin

Department of Neurosurgery, Faculty of Medicine, Universitas Padjadjaran-Dr. Hasan Sadikin General Hospital

\begin{tabular}{|c|c|}
\hline \multirow[t]{3}{*}{ Abstract } & $\begin{array}{l}\text { Objective: To compare the incidence of superficial surgical site infection after } \\
\text { posterior approach procedures between simple interrupted suture group } \\
\text { and hybrid mattress suture group. }\end{array}$ \\
\hline & $\begin{array}{l}\text { Methods: A number of } 38 \text { patients who underwent posterior approach } \\
\text { procedure were randomized into two groups. First group was sutured using } \\
\text { simple interrupted suture while the second was using hybrid mattress suture. } \\
\text { Bivariate statistical analysis was performed using Chi square test and Mann } \\
\text { Whitney test. The superficial surgical site infection incidence was evaluated } \\
\text { and recorded for both groups. }\end{array}$ \\
\hline & $\begin{array}{l}\text { Results: A superficial surgical site infection was found in } 26.3 \% \text { of the simple } \\
\text { interrupted group and no infection was found in the hybrid mattress group. } \\
\text { Statistical analysis showed a p value of } 0.046 \text {. }\end{array}$ \\
\hline $\begin{array}{l}\text { Received: } \\
\text { June 5, } 2014\end{array}$ & $\begin{array}{l}\text { Conclusions: Compared to simple interrupted suture, hybrid mattress } \\
\text { suture has less superficial surgical site infection in posterior approach for } \\
\text { spine surgery. }\end{array}$ \\
\hline $\begin{array}{l}\text { Revised: } \\
\text { July 22, } 2014\end{array}$ & $\begin{array}{l}\text { Keywords: Hybrid mattress suture, simple interrupted suture, superficial } \\
\text { surgical site infection, wound healing }\end{array}$ \\
\hline $\begin{array}{l}\text { Accepted: } \\
\text { August } 31,2015\end{array}$ & IJIHS. 2015;3(1):85-8 \\
\hline
\end{tabular}

\section{Introduction}

Surgical site infections are one of the major causes of morbidity and mortality of patients after surgery. ${ }^{1-4}$ Surgical site infections will lead to a longer antibiotic administration, prolonged hospitalization time, disruption of wound healing, implant removal, and increased likelihood of reoperation for debridement. . $^{24-8}$

Wound suture facilitates a good wound healing and prevents infection. Suturing the wound will prevent local ischemia that may lead to a decreased cellular proliferation, reduced defense against infection, and lower production of collagen, thus producing cumulative effect. ${ }^{9,10}$

This study aimed to compare the incidence of superficial surgical site infection after

\footnotetext{
Correspondence:

Ajid Risdianto, Department of Neurosurgery, Faculty of Medicine, Universitas Padjadjaran-Dr. Hasan Sadikin General Hospital

Jl. Pasteur No. 38, Bandung, Indonesia e-mail: ajidrisdianto@gmail.com
}

posterior approach between patients who underwent simple interrupted and hybrid mattress sutures.

\section{Methods}

A randomized prospective double blind study was conducted in patients who had undergone spine surgery with standard posterior approach. Patients were randomly divided into 2 groups; First group received simple interrupted suture while the second group received hybrid mattress suture.

After the posterior approach procedure, simple interrupted suture was performed by needle insertion at the edge of the wound to the contralateral side and continued with knot tying (Fig. 1a). The first hybrid mattress suture was performed as in simple interrupted suture, the second needle insertion was performed more medial and superior than the first needle insertion (Fig. 1b). Knot tying was performed 
after first and second insertion (Fig. 1c).

Observation was performed in patients surgical wound. Variables for observation were surgical wound scar formation, presence of pus, local edema, local tenderness, and redness of the wound. If redness on the edge of the operation wound was found, the diameter was classified into $<1 \mathrm{~cm}$ or $>1 \mathrm{~cm}$. If pus were present, standard culture and appropriate antibiotic treatment were performed. The presence of wound dehiscence was also recorded.

\section{Results}

A number of 38 patients were included in this study (Table 1). No difference was found between the study groups in terms of gender, age, diagnosis, and length of surgery with $\mathrm{p}$ $>0.05$ (Table 1). Surgical site infection rates were similar to the literature, showing the incidence of infection that ranges from 6\% to $8.7 \%$. In this study, superficial surgical site infection was more common in simple interrupted group (5 cases) than the hybrid mattress with a $p=0.46(p>0.05)$. Superficial surgical site infection include pus in 4 cases, erythema in 3 cases, and local edema in 1 case.

\section{Discussion}

Superficial surgical site infection is an infection of cutaneous and/or sub cutaneous tissue in the incision site. Local signs like pain, tenderness, redness, and local edema is a cardinal sign for superficial surgical site infection. Purulent drainage or isolate organism is another sign of this infection. ${ }^{1,2}$

Simple interrupted is a standard suturing technique that is performed after posterior approach. Hybrid mattress suturing technique has been used for other parts of the body with good results. The combination of wound edge eversion and wound edge tension distribution gives positive contribution in wound healing.

Superficial surgical site infection in the simple interrupted group can be influenced by several factors. Simple interrupted technique

\section{Table 1 Patients Characteristics}

\begin{tabular}{|c|c|c|c|}
\hline \multirow[b]{2}{*}{ Variable } & \multicolumn{2}{|c|}{ Group } & \multirow[b]{2}{*}{ p Value } \\
\hline & $\begin{array}{c}\text { Simple } \\
\text { Interrupted }\end{array}$ & $\begin{array}{c}\text { Mattress } \\
\text { Hybrid }\end{array}$ & \\
\hline Sex & & & 0.743 \\
\hline Male & 11 & 12 & \\
\hline Female & 8 & 7 & \\
\hline Age (yrs.) & & & 0.447 \\
\hline Median (range) & $40(20-60)$ & $36(17-61)$ & \\
\hline No of cases & & & 0.102 \\
\hline Infection & 3 & 4 & \\
\hline Degeneratif & 3 & 7 & \\
\hline Tumor & 7 & 6 & \\
\hline Trauma & 6 & 2 & \\
\hline Surgical duration & & & 0.669 \\
\hline Median (hours) & $2.95(2-4)$ & $2.95(2-5)$ & \\
\hline Superficial surgical site infection (no of cases) & & & 0.046 \\
\hline Infection & 5 & 0 & \\
\hline No infection & 14 & 19 & \\
\hline
\end{tabular}




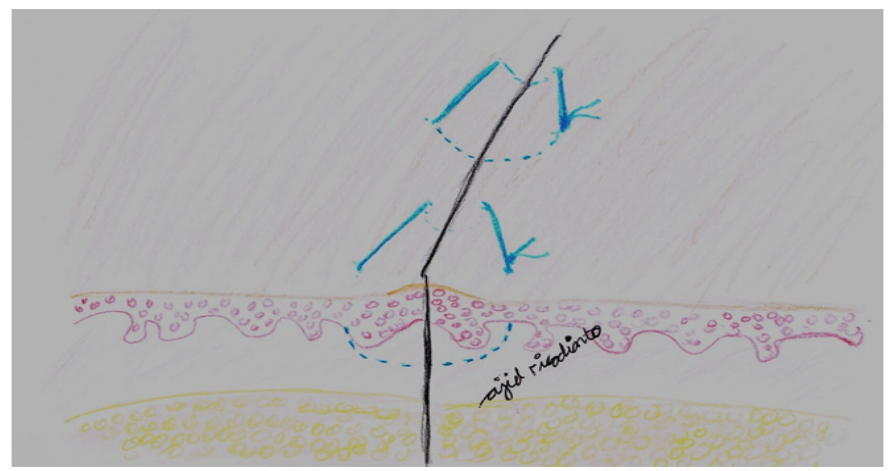

Fig. 1a Complete Simple Interrupted Suture Appearance. A single interrupted suture forms a loop to close the gap between wound edges.

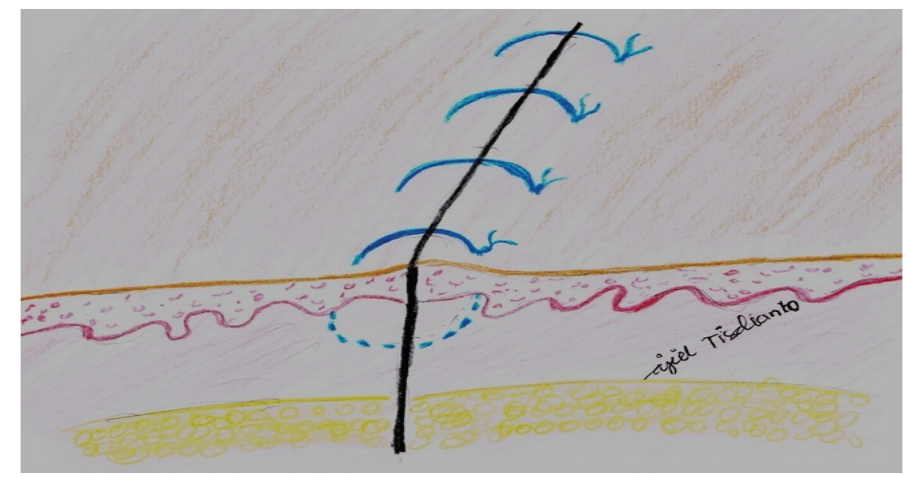

Fig. 1b Mattress Hybrid Suture, Needle Insertion is Performed in Sequence Number. The first needle insertion is performed from ipsilateral side to contralateral side $(1,2)$. The second needle insertion is performed from contralateral to ipsilateral side $(3,4)$. The second needle insertion is more medial and superior than the first insertion

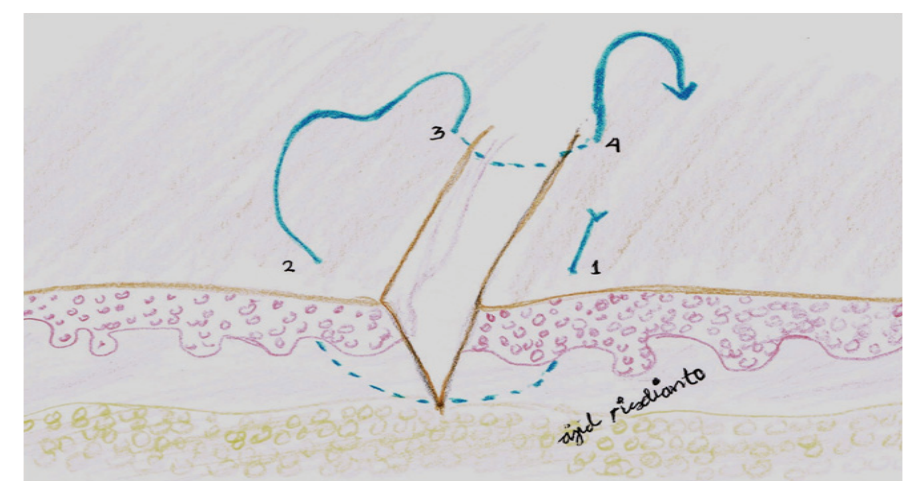

Fig. 1c Complete Hybrid Mattress Suture Appearance. The first loop is located more laterally and profunda, the second loop is located more medially and superficially. This combination creates a wound tension that is more evenly distributed 
tends to cause uneven distribution of strain injuries. Wound healing is influenced by this distribution of strain injuries while the selection of suturing techniques determines the distribution of the strain injuries. ${ }^{6,8}$

Good wound healing found in the hybrid mattresses group is probably due to the ability of eversion of the wound edges (Fig. 1c). ${ }^{7} \mathrm{~A}$ good edge eversion will provide good and flat wound healing. ${ }^{11}$ Wound edge eversion is important when the wound is in the concave area such as in the midline of the back. ${ }^{3}$

Good wound healing also requires a tight wound density and even strain injuries. The mattress hybrid suture technique is capable of providing even wound tension. ${ }^{11,12} \mathrm{~A}$ unique combination of tight wound density and equal strain injuries in the hybrid mattress suture technique is able to provide tight and evenly everted wound. ${ }^{4,11}$ All these give the advantage

\section{References}

1. Nasser R, Yadla S, Maltenfort MG, Harrop JS, Anderson DG, Vaccaro AR, et al. Complications in spine surgery. J Neurosurg Spine. 2010;13(2):144-57.

2. O'Toole JE, Eichholz KM, Fessler RG. Surgical site infection rates after minimally invasive spinal surgery. J Neurosurg Spine. 2009;11(4):471-6.

3. Vivas MJ, Kishan S, editors. Postoperative spinal wound infection and post procedural diskitis. New York: Marcel Dekhar; 2004.

4. Swanson KI, Ugokwe K, Zeidman SM, Ducker TB, Trost GR. Spine infection. In: Benzel EC, editor. Spine surgery. Philadelphia: Elsevier Saunder; 2012. p. 1875-91.

5. Anderson DJ. Surgical site infection. Infect Dis Clin North Am. 2011;25(1):135-53.

6. Mackay-Wiggan J. Suturing techniques. 2012 [updated 2012 May 17; cited 2013 Februari 21]. Available from: http://emedicine.medscape. com/article/1824895-overview\#showall.

7. Hoffman MD, Bielinski KB. Surgical pearl: the hybrid mattress suture. J Am Acad Dermatol. of wound healing and surgical infection that is characterized by the absence of local signs such as pus, local erythema, and edema as found in the simple suture group.

There were limitations in this study, such as patient's immune response, difference in skills of the operators, and systemic factors that influence the wound healing process. With the homogenous data that have been described above, this research is expected to provide a valid result.

In conclusions, superficial surgical site infection after posterior approach for spine surgery treated by hybrid mattress suture has less incidence compared to simple interrupted suture. Even though further study is required, the use of hybrid mattress suturing technique should be considered as the first choice for superficial surgical wound closure in patients with posterior approach procedures.
1997;36(5 Pt 1):773-4.

8. Wells C, Power L. Skin and wound care manual. 2008 [updated 2008; cited 2013 Februari 21]. Available from: http://westernhealth. nl.ca/uploads/PDFs / wound $\% 20$ care $\% 20$ manual $\% 20$ for $\% 20$ dianne $\% 20$ clements $\% 20$ final.pdf.

9. Griffin M. Basic of knot tying, suturing and application. World J Med Edu Res. 2013;3(1):75-9.

10. Yang C-S, Chen C-Y, Chiang C-H, Tung C-L, Chen $\mathrm{M}-\mathrm{Y}$, Yeh $\mathrm{C}-\mathrm{H}$, et al. The effect of suture size on skin wound healing strength in rats. J Med Biol Eng. 2010;31(5):339-43.

11. Moody BR, McCarthy JE, Linder J, Hruza GJ. Enhanced cosmetic outcome with running horizontal mattress sutures. Dermatol Surg. 2005;31(10):1313-6.

12. Kirkner R, Falanga V, Ford HR, Wilson SE. Surgeon's roundtable: reducing surgical site infections. Suppl Contemp Surg. 2003:51-8. 